https://doi.org/10.15407/ujpe66.2.166

B. GHULE, M. LAAD

Symbiosis Institute of Technology (SIT), Symbiosis International (Deemed University) (SIU)

(Lavale, Mulshi Taluka, Pune, Maharashtra 412115, India; e-mail: meena@sitpune.edu.in;

babaji.ghule.phd2019@sitpune.edu.in)

\title{
POLYMER COMPOSITES \\ WITH IMPROVED DIELECTRIC PROPERTIES: A REVIEW
}

\begin{abstract}
Materials exhibiting high dielectric constant $(k)$ values find applications in capacitors, gate dielectrics, dielectric elastomers, energy storage device, while materials with low dielectric constant are required in electronic packaging and other such applications. Traditionally, high $k$ value materials are associated with high dielectric losses, frequency-dependent dielectric behavior, and high loading of a filler. Materials with low $k$ possess a low thermal conductivity. This creates the new challenges in the development of dielectric materials in both kinds of applications. Use of high dielectric constant filler materials increases the dielectric constant. In this study,the factors affecting the dielectric constant and the dielectric strength of polymer composites are explored. The present work aims to study the effect of various parameters affecting the dielectric properties of the materials. The factors selected in this study are the type of a polymer, type of a filler material used, size, shape, loading level and surface modification of a filler material, and method of preparation of the polymer composites. The study is focused on the dielectric enhancement of polymer nanocomposites used in the field of energy storage devices. The results show that the core-shell structured approach for high dielectric constant materials incorporated in a polymer matrix improves the dielectric constant of the polymer composite.
\end{abstract}

Keywords: polymer composites, dielectric constant, dielectric strength, ceramic filler, energy storage.

\section{Introduction}

Energy storage devices, bypass capacitors used in microelectronics, electronic devices working at high operating frequency widely use dielectric materials with high dielectric constants [1-3]. Miniaturization of electronic devices demands the low dielectric constant material for the packaging and insulating materials $[4,5]$. Therefore, the synthesis of both types of materials has created a lot of interest among the researchers today. The materials with high dielectric constant should have high dielectric strength, low dielectric losses, chemical resistance, frequencyindependent response, and good mechanical properties for its desired applications. It is hard to get the unique combination of all properties in one component material. Usually, ferroelectric ceramics show a high dielectric constant and low losses, but these materials are generally brittle in nature. Due to their

(C) B. GHULE, M. LAAD, 2021 brittleness, it is difficult to fabricate a complex shape. Even the processing of ceramic substrates during the circuit fabrication [5] becomes difficult due to their brittle character. In addition, ceramic materials have poor dielectric strength. Polymers exhibit good dielectric strength, stability in chemical attack, hydrophobic and restraint in temperature, and are also easy to be treated, but have very small value of the dielectric constant $(k<10)$, which limits the scope of their application [1-3, 6, 7]. High dipole density polymers can have high energy density [8]. In addition, they have a high dielectric strength. Therefore, for high energy density capacitors, polymers are the best suited dielectric materials. To meet desired dielectric properties, composites of polymers with metals, semiconductors, metal oxides, and ceramics are synthesized using a variety of filler materials.

To achieve the desired properties in dielectric composites, the connectivity between filler and matrix materials is very important. In a multiphase mate-

ISSN 2071-0194. Ukr. J. Phys. 2021. Vol. 66, No. 2 


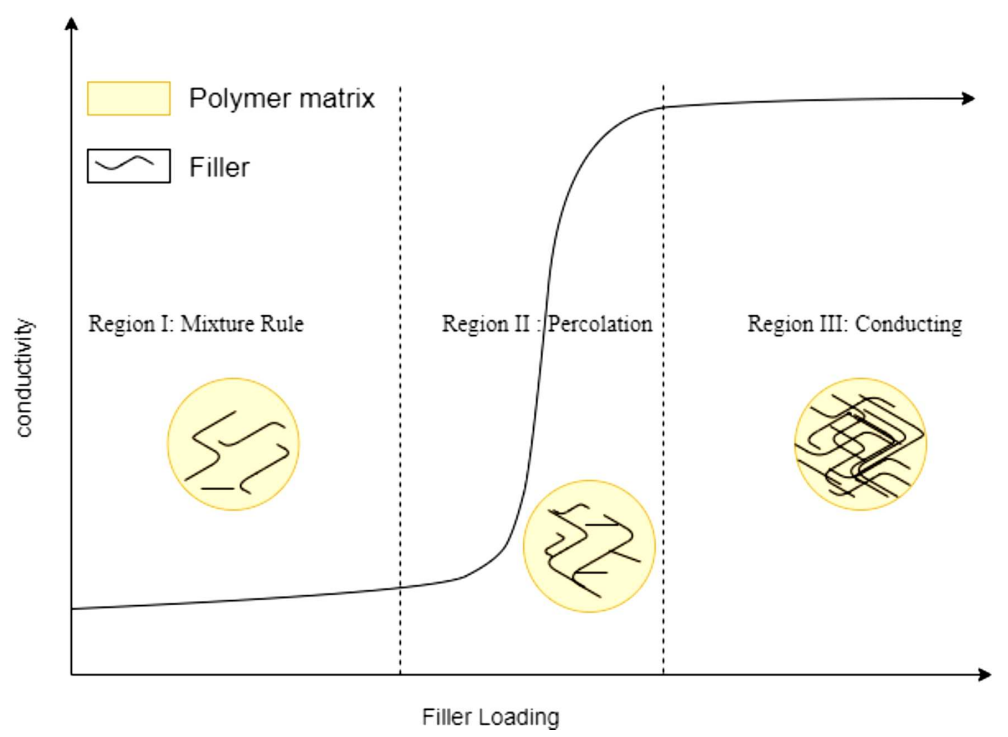

Fig. 1. Change in the conductivity of a filler in the matrix at various loading levels

rial, the interspatial relationships are described by the concept of connectivity which affects all properties of the composites. The filler dimension, interfacial properties, percolation threshold, and porosity affect the properties of composites [5, 9, 10]. Therefore, different factors are considered, while designing the composite material such as a matrix polymer, filler, size and shape of a filler, surface treatment of filler, hybridization of a filler, synthesis method, etc. [11]. This review article focuses on the thermoset, thermoplastic materials both polar and non-polar polymers like polyvinylidene fluoride (PVDF), polyvinylidene fluoride trifluoro-ethylene $\mathrm{P}(\mathrm{VDF}-\mathrm{TrFe})$, cynoresin polymer, polypropylene $(\mathrm{PP})$, polystyrene (PS) etc.

\section{Theoretical Models for Composites}

The relative permittivity (dielectric constant) of a material is related to its capacity of energy storage, when a potential is applied across it. The energy density stored in a material is related to the macroscopic property called the polarization [9]. The energy density $(U)$ stored in a dielectric material is governed by the applied electric field $(E)$ and electric displacement (D) as,

$U=\int E d D$
For linear dielectrics,

$U=\frac{1}{2} D E=\frac{1}{2} \varepsilon_{0} k E_{b}^{2}$,

where, $E_{b}, k$, and $\epsilon_{0}$ are the breakdown field strength, effective permittivity (dielectric constant) of the composite, and permittivity of vacuum, respectively. In nanocomposite materials, the loading level of a nanoparticle filler should be rationally chosen in such a way that the combination of $k$ and $E_{b}$ gives the maximum energy density $[7,8,12-17]$. In dielectric composites, especially those with the $0-3$ connectivity, the percolation level plays an important role. The volume fraction of filler particles at which initially isolated inclusions get interconnected and distort the pure $0-3$ connectivity called percolation threshold [18]. Particles of certain size and shape have clearance (matrix material) between neighbouring particles below the percolation threshold. The mean percolation threshold depends on the shape and size distributions of particles [9]. For conductive fillers, the percolation is defined as a change in the dispersion state of the conducting phase of a composite. The percolation threshold is the minimum volume content of the conducting filler, where the drastic change in the electrical conductivity begins [19]. Figure 1 shows changes in properties of polymer composites at the percolation threshold. It is clear from Fig. 1 that, as the volume fraction 
of filler particles increases, initially isolated inclusions get interconnected with the polymer matrix and significantly affect the conducting properties of the matrix. Percolation theory of dielectric composite suggests,

$k=k_{0}\left|\frac{f_{c}-f_{\text {filler }}}{f_{c}}\right|^{-q}$,

where, $k$ is the effective dielectric constant of a composite, $k_{0}$ the dielectric constant of the matrix, $f_{c}$ the percolation threshold, $f_{\text {filler }}$ the volume fraction of a filler, and $q$ is the critical exponent [20].

For the mechanical flexibility of PVDF, a low percolation threshold is required. It is obtained by introducing graphene nanoparticles in PVDF with large $k$ $(k>200)$ at the percolation threshold $f_{c}$ [21]. The research study reported on that, at a low percolation threshold, $k$ up to 806 can be obtained by introducing $\mathrm{SiC}-\mathrm{CNT}$ in PVDF [22].

The effective dielectric constant of a composite material is a function of the dielectric constant of individual constituents, filler loading level, size and shape of filler particles, dispersion of filler particles, dielectric displacement, etc. Various models are proposed to explain the dielectric properties of composites. Mixing equations proposed by theoretical models are based on electrostatic theories. Moreover, some mixing equations have a stronger empirical background. When the effective dielectric constant and volume fractions of individual constituents are measurable, then the properties of the material components can be derived using some mixing equations $[9,23]$.

Dielectric properties are also influenced by the dispersion of a filler in the matrix, morphology, and interactions between the two phases [5]. Many composites deviate from the ideal configuration due to the clustering of a filler and an increase in the porosity [23]. Theoretical models proposed to predict the dielectric constant of a composite are as follows:

1) Average Mixing Model

$k=v_{1} k_{1}+v_{2} k_{2}$

2) Maxwell-Garnett

$k=k_{2}+2 v_{1} k_{2}\left[\frac{k_{1}-k_{2}}{k_{1}+k_{2}-v_{1}\left(k_{1}-k_{2}\right)}\right] ;$
3) Lichtencher formula (Classical model of logarithmic mixing rule)

$\ln k=v_{1} \ln k_{1}+v_{2} \ln k_{2} ;$

4) Power mixing rule

$k^{\beta}=v_{1} k_{1}^{\beta}+v_{2} k_{2}^{\beta}$.

By the Bitcher formula, $\beta=\frac{1}{2}$, and, by the Looyenga formula, $\beta=\frac{1}{3}$.

Here, $k$ is the effective dielectric constant of composites, $k_{1}, k_{2}$, and $v_{1}, v_{2}$ are the dielectric constants and the volumes of a filler and a matrix polymer, respectively [24]. Dielectric loss is a complicated phenomenon. Therefore, a relatively few theoretical models are available for the prediction of a loss factor or loss tangent. The general mixing model predicts theoretical values in good agreement with experimental data. We have

$\left(\tan \delta_{c}\right)^{\alpha}=\sum v_{f i}\left(\tan \delta_{i}\right)^{\alpha}$

where $\tan \delta_{c}, \tan \delta_{i}$, and $v_{f} i$ are the loss tangent of the composite material, loss tangent of $i_{t} h$ material, and volume fraction of the $i_{t} h$ material, and $\alpha$ is a constant which determines the mixing rule.

The relation $\alpha=-1$ means the serial mixing, $\alpha=+1$ the parallel mixing, and $\alpha=0$ gives the logarithmic mixing rule [5]. It is affected by the presence of moisture or humidity. Dielectric losses in a material may arise due to intrinsic or extrinsic imperfections in the crystal lattice. The proper processing of materials minimizes the losses due to extrinsic imperfections. Dielectric losses due to different types of defects show different temperature and frequency dependences. A hydrophilic filler like Al adsorbing humidity can affect dielectric losses [5, 9]. Dielectric properties of composites are frequency-dependent. Different physical processes such as dielectric resonance, dielectric relaxation, electrical conduction, and loss from non-linear processes cause the dissipation of the electrical energy leading to dielectric losses in materials $[9,25]$.

Generally, the theoretical models applicable for low loading and increasing filler contents show diverse results. This occurs, because, at higher loadings, there is an imperfect dispersion of ceramic filler particles in the matrix and due to air trapped or the porosity of the composite. Another reason for this deviation

ISSN 2071-0194. Ukr. J. Phys. 2021. Vol. 66, No. 2 
in results is due to the fact that a theoretical model does not consider the matrix-filler interphase interactions. These predictions are found to be in agreement for composites which have nearly same relative permittivity values for a filler material and the matrix $[5,9,10]$.

\section{Factors Affecting Dielectric Properties of Composites}

\subsection{Polymer material}

Polymer composites show different properties, and those properties depend on whether the polymer used as a matrix is a thermoplastic polymer or thermoset polymer. Such property as the melting temperature is associated with a thermoplastic polymer, while the thermoset polymer shows a dimensional behavior which is characterized by its glass transition temperature $\left(T_{g}\right)$. Thermoplastic polymer composites require no curing and show the unlimited shelf life, reprocess ability, lower moisture absorption, chemical inertness, higher service temperature, and high environmental tolerance compared to thermoset matrix composites, but show a relatively high viscosity and processing difficulties [26]. Even at a high filler loading (60 vol\%), thermosetting composites exhibit a low porosity, but a high moisture absorption and low tensile strength. It is difficult to use thermoset composites in extreme chemical environments. Polyphenylene oxide (PPO), poly(tetrafluoroethylene) (PTFE), polyetherimide (PEI), etc., are the major thermoplastic polymer matrices having frequency- independent dielectric properties in the microwave frequency region (9). A research study has reported on that composites like $\mathrm{Al}_{2} \mathrm{O}_{3} / \mathrm{PEI}, \mathrm{MgO} / \mathrm{PEI}, \mathrm{SiO}_{2} / \mathrm{PEI}, \mathrm{BaTiO}_{3} / \mathrm{PEI}$, $\mathrm{BN} / \mathrm{PEI}$ polyethrmide(PEI) have dielectric constants independent of the nanofiller type [27]. Polymetyl methacrylate (PMMA) is good for low- $k$ polymer composites [28].

The polar polymer increases the dielectric constant of a composite material at low frequencies, but has hardly any effect at microwave frequencies [5]. PVDF has low water absorption characteristics and, due to the polar nature, exhibits a high $k>10$ value $[8,29]$. Cynoresins have high polarity cyno groups as side chains which exhibit the dielectric behavior. Because of a polar backbone, the polar polymers show a strong affinity for inorganic oxides [30, 31]. It was reported on the synthesis of low- $k$, low-density $\mathrm{Mg}_{2} \mathrm{SiO}_{4} / \mathrm{PTFE}$ composite, with $k$ value remaining almost constant throughout the frequency spectrum 0.5 to $3 \mathrm{MHz}[23]$.

\subsection{Filler materials}

Research studies have reported on the use of a conductive or semiconductor filler which increases the interfacial polarization between a filler and the polymer matrix, thereby enhancing the dielectric constant of the composite $[19,32]$. The conducting filler dispersed in an insulating matrix exhibits a high permittivity near the percolation point of the conducting phase [33]. A conductive or semiconductor filler leads to large dielectric losses. The use of highly polarizable conjugated polymers enhances the dielectric constant to a good extent, but the dielectric loss also increases proportionally, as the conduction occurs due to the formation of a conductive path [3, $20,24]$. Because of a conductive filler, the dielectric constant increases, but the dielectric strength significantly decreases [34]. For a conductive or semiconductor filler, the dielectric loss is large [9]. For a conductive filler, the dielectric constant of a composite depends on the interparticle distance. A variation in the critical value of the interparticle distance in composites is found to depend on the conductivity of the filler, nature of polymer used etc. [19]. With the help of a small-size ferroelectric ceramic filler, the high dielectric constant is obtained [1, 4, 35]. Ceramic nanofillers with large aspect ratio are preferred to their spherical counterparts for the improvement of $E_{b}$ of nanocomposites [36]. The dielectric strength of $\mathrm{SiO}_{2} / \mathrm{PE}$ composites does not depend on the degree of crystallinity [37]. K. Yang et al. reported dielectric properties for $\mathrm{ZnO} / \mathrm{PVDF}$ composites with respect to the filler structure. For commercial $\mathrm{ZnO}$, $k=19.4$, and the dielectric strength is equal to $45 \mathrm{kV} / \mathrm{mm}$; for flower-like $\mathrm{ZnO}, k=221.1$, and the dielectric strength is equal to $42 \mathrm{kV} / \mathrm{mm}$; for walnutlike $\mathrm{ZnO}, k=104.9$, and the dielectric strength is equal to $40 \mathrm{kV} / \mathrm{mm}$ [32].

In $\mathrm{PP} / \mathrm{BaTiO}_{3}$ and $\mathrm{PP} / \mathrm{TiO}_{2}$ composites, metal oxide fillers do not affect the breakdown strength of a filler [16, 38]. Another group of researchers investigated transparent $\mathrm{TiO}_{2} /$ polyvinyl-alcohol(PVA) and $\mathrm{TiO}_{2} /$ PMMA nanocomposites exhibiting high $k$ values of 24.6 and 26.8, respectively [39]. The dielec- 


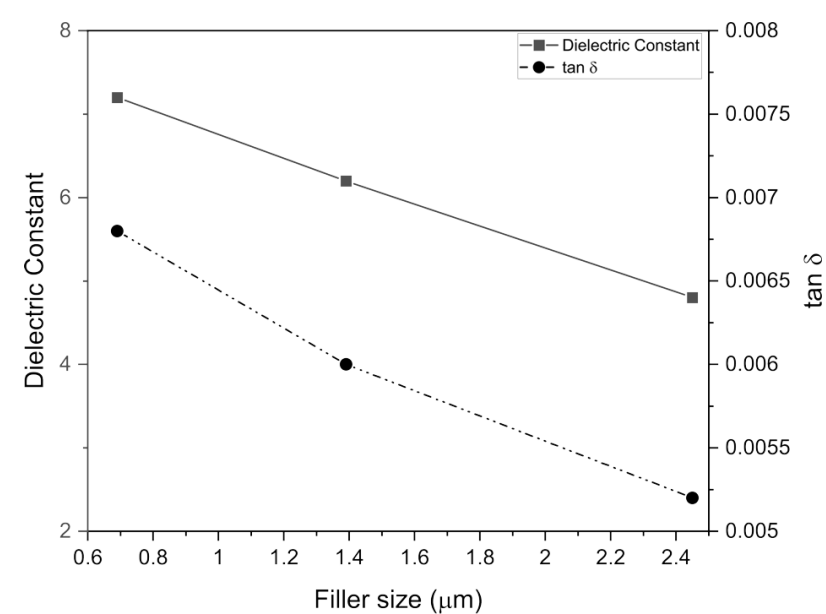

Fig. 2. Variation of the dielectric constant and dielectric losses with the filler size

tric constant of polydimethylsiloxane (PDMS) was reported to be improved by introducing graphene oxide as a filler by a research study [40].

\subsection{Dielectric and thermally conducting fillers}

The application of dielectric materials as fillers enhances the dielectric constant of a composite significantly. When a thermally conducting filler is used, the dielectric constant increases considerably, but the dielectric strength decreases drastically. The introduction of high dielectric constant materials like $\mathrm{BaTiO}_{3}, \mathrm{BST}, \mathrm{BNN}$ s enhances the dielectric constant, dielectric strength and gives a superior power density at very low volume $[7,12,41]$. S.H. Yao et al. showed that the addition of the thermally conducting filler $\mathrm{Al}_{2} \mathrm{O}_{3}$ decreased the dielectric strength of $\mathrm{Al}_{2} \mathrm{O}_{3} / \mathrm{BaTiO}_{3} / \mathrm{PP}$, while the addition of a high dielectric constant filler material increased the dielectric strength in $\mathrm{Al}_{2} \mathrm{O}_{3} / \mathrm{BaTiO}_{3} / \mathrm{PP}$ [35].

\subsection{Filler size and shape}

The dielectric constant of a material mainly depends on the interfacial polarization. As the size of filler particles decreases, the effective surface area of a filler in contact with the matrix polymer increases leading to an increase in the interfacial polarization which further enhances the dielectric constant, but decreases the dielectric strength [6, 19]. N. Guo et al. synthesized nanocomposites and observed that rodshaped nanofillers exhibited a higher dielectric con- stant than the nanocomposite prepared using spherical nanofillers [16]. A research study has reported on that needle-shaped $\mathrm{TiO}_{2}$ fillers increased the dielectric constant more than the spherically shaped $\mathrm{TiO}_{2}$ fillers, when composed with polymeric cholesteric liquid crystals at a lower volume than spherical ones [42]. Another investigation reported on that, as the filler size was reduced to the nano scale, the dielectric loss increased effectively as nanoparticles exhibited a tendency to agglomerate. Nanocomposites possessed a higher dielectric loss than microcomposites, higher moisture absorption and porosity [23]. Nanocomposites were observed to enhance the dielectric response by the addition of a very small amount of an inorganic filler, whose $k$ is almost equal to that of a polymer [27]. For a polymer matrix, the percolation threshold was found to depend mainly on the filler shape and dimension [43]. Studies have reported on that nanorod composites could easily achieve the percolation threshold [20]. The nanofiller approach increases the $k$ value of polymer composites, but it affects the dielectric strength $E_{b}$ of a composite material. The existence of an inhomogeneous field distribution owing to the large difference in $k$ values of a ceramic nanofiller and the polymer matrix which yielded sharply decreasing $E_{b}$ of the nanocomposites [7]. $\mathrm{BaTiO}_{3} / \mathrm{PP}$ and $\mathrm{TiO}_{2} / \mathrm{PP}$ achieved a high energy density of $9.4 \mathrm{~J} / \mathrm{cm}^{3}$. Rod-shaped $\mathrm{TiO}_{2}$ exhibited a high $k$ and a low breakdown strength than spherical ones $[16,38]$. It was observed that spherical nanoparticles of $\mathrm{BaTiO}_{3}$ could be used for enhancing the electrical polarization, while hexagonal boron nitride nanosheets and MMT nanoplatelets were more suitable for increasing the dielectric breakdown strength [31]. M. Chun reported on that, as the size of $\mathrm{BaNd}_{2} \mathrm{Ti}_{4} \mathrm{O}_{1} 2$ filler decreases from $2.45 \mathrm{~mm}$ to $0.69 \mu \mathrm{m}$, the dielectric constant and $\tan \delta$ decrease from 7.2 to 4.8 and 0.0068 to 0.0052 , respectively. This variation of the dielectric constant and dielectric losses with the filler size is plotted in Fig. 2 [31].

\subsection{Filler loading}

An increase in the filler content greatly increases the dielectric constant. But the large content of a ceramic filler makes the composite bulky and increases the loss of flexibility and results in the poor dispersion of a filler $[3,24]$. The loading of a filler affects the dielectric loss and strength of a composite as

ISSN 2071-0194. Ukr. J. Phys. 2021. Vol. 66, No. 2 
well. B.K. Sharma et al. showed that the loss factor decreased with the addition of $\mathrm{ZnO}$ in the polyaniline (PANI) matrix [46]. Y. Deng et al. reported on that the dielectric loss increased with the loading of $\mathrm{Bi}_{2} \mathrm{~S}_{3}$, as $\mathrm{Bi}_{2} \mathrm{~S}_{3}$ is a semiconductor [20]. At a low filler loading, the composites exhibited high $k$ and a high dielectric strength. Incorporating metal oxide $\mathrm{BaTiO}_{3}$ and $\mathrm{TiO}_{2}$, the high energy composite $\left(U=9 \mathrm{~J} / \mathrm{cm}^{3}\right)$ was obtained with no influence on the dielectric strength of PP [47]. Figure 3 shows a variation of the dielectric constant with the filler loading with reference to the theoretical model.

Table 1 shows the effect of filler loading on different polymer composites:

\subsection{Composite microstructure}

High dielectric constant can be achieved by reinforcing the polymer matrix by a filler with high dielectric constant or by a higher loading of the filler. A reduction in the size of a filler improves the dielectric constant of composites. But it comes with associated problems such as: at a higher loading, the material becomes bulky, and there occurs a derioration of mechanical properties. Nanoparticles have a tendency to agglomerate. In addition, due to the formation of a local field, the dielectric strength of a composite reduces significantly. Nanocomposites possess high moisture absorption and porosity resulting in high dielectric losses. The large interface volume of a nanocomposite causes an increase in the loss factor and a decrease in the dielectric strength [9]. With the objective of designing a composite at a lower loading with maximum extractable energy, a hybrid composite can be produced with a proper core-shell structure. Results have been reported with high $k$, low loss and high energy density with hybrid composite approach. M. Roy et al. showed that, for microfilled composites, the dielectric strength is less than for a nanofilled composite in polyethylene $/ \mathrm{SiO}_{2}$ [37]. T.S. Sasikala et al. showed that nanocomposites exhibites higher loss as compared with microcomposites in $\mathrm{Mg}_{2} \mathrm{SiO}_{4}$ / PTFE [23].

\subsection{Surface treatment}

Interface compatibility of an inorganic filler and an organic polymer is very weak, since their properties are completely different, which affects the dispersion of a filler in the matrix. The surface treatment of filler particles or the core-shell structured approach significantly enhances the dielectric constant, reduces the loss factor, and decreases the frequency dependence [32]. The homogeneous dispersion of a nanofiller can be achieved even at a high loading. Simultaneously, the dielectric constant of a composite can be effectively enhanced with a reduction in the dielectric loss and maintaining the dielectric strength at the same time [58, 59]. Zhou showed that the dielectric constant of AlN can be improved with surface treatment [29]. Cheng Yang et al. reported on that multi-walled carbon nanotubes (MWCNT) treated with polypropylene show a good dispersion in polystyrene and a reduced leakage current [53]. In PS/MWCNT composite, bare carbon nanotubes (CNT) lead to a huge dielectric loss. MWCNT treated with polypropylene show a good dispersion in polystyrene and a reduced leakage current [53]. Ceramic fillers increase the density and porosity of composites with loading. At a low porosity, the uniform dispersion and good adhesion are observed between a ceramic filler and the polymer matrix. T.S. Sasikala and M.T. Sebastian reported on that silane-treated composites showed a lower porosity [23]. The silane treatment and the coupling agent formed a strong bond between the organic and inorganic phases. K.S. Shah et al. showed that the silane-treated montmorillonite clay composite not only showed a higher $k$ value, but also a higher dielectric strength [55]. Three-phase composites restricted a decrease in the dielectric strength due to the addition of nanofillers [6]. Another study reported on that the $\mathrm{Al}_{2} \mathrm{O}_{3}$ shell layer reduced the interfacial polarization, electrical conduction, and electric field concentration which, in turn, enhances the dielectric strength and decreases the loss factor [59].

\subsection{Methods of experimentation}

Three general methods are used to disperse a nanofiller in the polymer matrix. A) direct mixing B) in situ polymerization in the presence of nanoparticles, and C) in situ formation of nanoparticles with simultaneous polymerization $[3,28]$. In the conventional blending of the two components, the method raises the issues of inhomogeneity and aggregation [60]. In first two methods, filler particles do not disperse uniformly in the matrix polymer, as the polymerization of organic monomers and the formation of guest particles are separately carried out [28]. The in situ formation limits the size of nanoparticles 
Table 1. Effects of filler loading on polymer composites

\begin{tabular}{|c|c|c|c|}
\hline Sr. No. & Polymer & Filler & Feature \\
\hline 1 & Silicon & $\begin{array}{l}\text { Polyethyline glycol } \\
\text { (PEG) }\end{array}$ & $\begin{array}{l}\text { Addition of filler content in matrix increased } k \text { value and loss } \\
\text { factor [24] }\end{array}$ \\
\hline 2 & Polyaniline (PANI) & $\mathrm{Fe}_{3} \mathrm{O}_{4}$ & $k$ value and loss factor both decreased with loading of $\mathrm{Fe}_{3} \mathrm{O}_{4}[48]$ \\
\hline 3 & $\begin{array}{l}\text { Polymethyl vinyl } \\
\text { siloxane (VMQ) }\end{array}$ & $\begin{array}{l}\text { Hexagonal boron } \\
\text { nitride(HBN) }\end{array}$ & $k$ value and loss factor improved with increasing HBN content [49] \\
\hline 4 & $\begin{array}{l}\text { UHMWPE/LLDPE } \\
\text { blend }\end{array}$ & $\mathrm{Al}_{2} \mathrm{O}_{3} / \mathrm{Si}_{3} \mathrm{~N}_{4}$ & $k$ value and loss factor decreased with loading [50] \\
\hline 5 & $\begin{array}{l}\text { Polyvinylidine } \\
\text { difluoride (PVDF) }\end{array}$ & Al & $\begin{array}{l}k \text { value increased with loading and no variation was observed in } \\
\text { loss factor upto } 60 \mathrm{wt} \% \text { of filler [51] }\end{array}$ \\
\hline 6 & Polystyrene (PS) & $\mathrm{TiO}_{2}$ & With loading of filler, $k$ value increased and loss factor decreased [43] \\
\hline 7 & PS & $\mathrm{BaTiO}_{3}$ & $\begin{array}{l}\text { Addition of filler content in matrix increased both } k \text { value and } \\
\text { dielectric loss [32] }\end{array}$ \\
\hline 8 & $\begin{array}{l}\text { Cyclic olefin } \\
\text { copolymer (COC) }\end{array}$ & $\mathrm{BST}$ & $\begin{array}{l}\text { Gradual increase in } k \text { value and loss factor with BST loading was } \\
\text { observed [52] }\end{array}$ \\
\hline 9 & PS & MWCNT@PPy & $\begin{array}{l}\text { Increasing wt } \% \text { of MWCNT increased } k \text { and loss factor but } \\
\text { breakdown strength was decreased [53] }\end{array}$ \\
\hline 10 & PVDF & $\mathrm{SiC}-\mathrm{CNT}$ & $\begin{array}{l}\text { Loading of filler increased } k \text { value and loss factor. Highest value of } \\
k=8700 \text { was obtained at } 2.3 \mathrm{vol} \% \text { of CNT }[22]\end{array}$ \\
\hline 11 & PS & $\mathrm{BaTiO}_{3}-\mathrm{PMMA}$ & $\begin{array}{l}k \text { value increased with loading of } \mathrm{BaTiO}_{3} \text {. Highest extractable energy } \\
2 \mathrm{~J} / \mathrm{cm}^{3} \text { was obtained at field strength } E_{b} 220 \mathrm{kV} / \mathrm{mm} \text { for } 22 \mathrm{vol} \% \\
\mathrm{BaTiO}_{3}[54]\end{array}$ \\
\hline 12 & $\begin{array}{l}\text { Polytetrafloroethylene } \\
\text { (PTFE) }\end{array}$ & $\mathrm{Mg}_{2} \mathrm{SiO}_{4}$ & $k$ value and loss factor both were increased with loading of filler [23] \\
\hline 13 & Polypropylene (PP) & $\mathrm{BaTiO}_{3}, \mathrm{TiO}_{2}$ & $\begin{array}{l}\text { At low volume fraction of inorganic filler, } k \text { value of nanocomposite } \\
\text { moderately increased with loading }[16,38]\end{array}$ \\
\hline 14 & $\begin{array}{l}\text { High Density } \\
\text { Polyethylene (HDPE) }\end{array}$ & Montmorillonite clay & $\begin{array}{l}\text { Increase in clay content increased the } k \text { value. Dielectric strength } \\
\text { increased upto } 5 \mathrm{wt} \% \text { filler content [55] }\end{array}$ \\
\hline 15 & Cynoresin (CRS) & $\mathrm{TiO}_{2}$ & $\begin{array}{l}\text { Nanocomposite showed ultrahigh } k \text { which was found to increase with } \\
\text { loading. Loss factor remained low }<0.3[30]\end{array}$ \\
\hline 16 & PVDF & $\begin{array}{l}\text { Boron nitride } \\
\text { nanosheet (BNNS), } \\
\text { Barium Strontium } \\
\text { Titanate (BST) }\end{array}$ & $\begin{array}{l}\text { This is trilayered composite. Increase in BNNS content beyond } \\
10 \mathrm{vol} \% \text { resulted in systematic decrease in dielectric strength. } \\
\text { Both } k \text { and loss factor increased with loading of BST. Superior } \\
\text { power density } 0.91 \mathrm{MW} / \mathrm{cm}^{3} \text { more than BOPP [7] }\end{array}$ \\
\hline 17 & $\begin{array}{l}\text { Cynoethylated } \\
\text { Cellulose (CRS) }\end{array}$ & Montmorillonite clay & $\begin{array}{l}\text { Loading above } 5 \text { wt } \% \text { showed that composite exhibited high } k \text { value } \\
\text { but decreased with clay loading [56] }\end{array}$ \\
\hline 18 & PVDF-HFP & 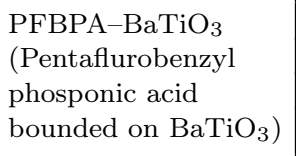 & $\begin{array}{l}\text { Increased filler content decreased the dielectric strength. } k \text { value } \\
\text { increased with loading and attained maximum at } 50-60 \text { vol\% of filler. } \\
\text { Beyond this } \mathrm{k} \text { value showed a decrease [12] }\end{array}$ \\
\hline 19 & $\begin{array}{l}\text { Benzocyclobutane } \\
(\mathrm{BCB})\end{array}$ & BNNS & $\begin{array}{l}\text { Dielectric strength of composites improved to } 403 \mathrm{MV} / \mathrm{m} \text { on addition } \\
\text { of } 10 \mathrm{vol} \% \text { BNNS in matrix [57] }\end{array}$ \\
\hline
\end{tabular}

and prevents their agglomeration [3]. In the recent years, the third component in two-phase composite systems is introduced. Y. Li et al. obtained a high value of the dielectric constant by adding the third

172 component in a two- phase PVDF composite, i.e., for $\mathrm{PVDF} / \mathrm{BT} / \beta-\mathrm{SiC}, k($ high $)=325$ with $40 \mathrm{vol} \%$ $\mathrm{BaTiO}_{3}$ and 17.5 vol\% $\beta$-SiC [34]. The dielectric constant of PDMS(3.1) was improved to 5.5 at $1 \mathrm{GHz}$ by 
introducing core shell $\mathrm{Fe}$ covered by $\mathrm{SiO}_{2}\left(\mathrm{Fe}-\mathrm{SiO}_{2}\right)$, and $k$ was increased to 9.8 , when Fe was covered by $\mathrm{TiO}_{2}\left(\mathrm{Fe}-\mathrm{TiO}_{2}\right)[61]$.

\subsection{Porosity}

Porosity is one of the prime factors affecting the dielectric properties of inorganic and polymer-based composites. In ceramics, the porosity is not desirable, as usual. The porosity is minimized, and the permittivity and dielectric losses of ideal fully dense ceramics are estimated by the porosity. The porosity reduces the breakdown voltage, by resulting in the degradation of the electrical reliability performance of a dielectric material, but does not affect the leakage current. It can be concluded that the use of the fillers with a low dielectric constant or increased porosity of a material lowers the dielectric constant of the composite material [9].

\subsection{Dielectric properties of polymer composites}

Most of the commercially available electrostatic capacitors possess energy densities in the range of 18 to $29 \mathrm{~J} / \mathrm{cm}^{3}$. Biaxially oriented stretched polypropylene $(\mathrm{BOPP})$ is the best dielectric material currently used in electronic circuits due to its high dielectric strength $(>700 \mathrm{MV} / \mathrm{m})$ and low dielectric losses $(<0.02 \%)$. BOPP possesses $U=2 \mathrm{~J} / \mathrm{cm}^{3}$ with $k$ value $2-3[36]$. Polypropylene is a tough, crystalline, rigid, the lightest, and cheapest thermoplastic polymer. It has excellent piezoelectricity [47]. It possesses a high dielectric strength of $\sim 200 \mathrm{MV} / \mathrm{m}$ [3]. N. Guo et al. synthesized polyproylene (PP) composites with $\mathrm{BaTiO}_{3}, \mathrm{TiO}_{2}, \mathrm{ZrO}_{2}$ and showed that $\mathrm{BaTiO}_{3}$ composite possesses the highest energy $\left(U=9.4 \mathrm{~J} / \mathrm{cm}^{3}\right)$ at $13.6 \mathrm{vol} \% \mathrm{BaTiO}_{3}[16]$. But the use of $\mathrm{PP}$ is limited due to a low dielectric constant [36]. High dipole density polymers provide a potential to increase the energy density. Poly(vinylidene fluoride) (PVDF) and its copolymer trifluoroethylene (TrFE) are polar-polymers, the best known ferroelectric polymers. These polymers have been widely used in actuators and electro-mechanical sensors [8]. PVDF is a tough, stable, semicrystalline thermoplastic ferroelectric polymer. PVDF has low density in comparison with other fluro-polymers. PVDF exhibits the high chemical resistance and compatibility among thermoplastic materials. PVDF has sturdy tensile strength and contains two fluorine groups which show an in-

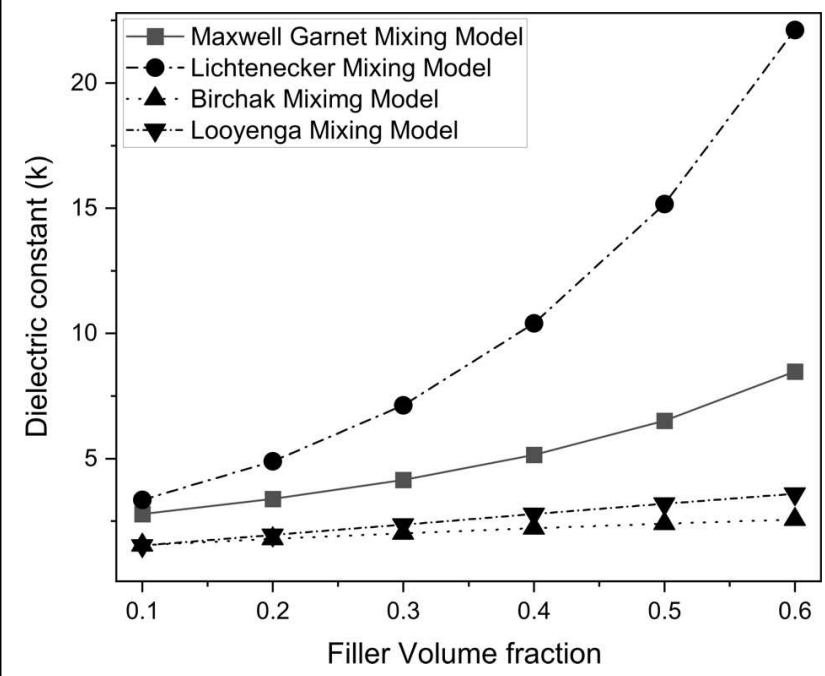

Fig. 3. Variation of the dielectric constant with filler volume fraction

tense polarity [47]. Zhou showed that the Al filler decreases the degree of crystallinity of composites. High $k$ value $(k=230)$ is obtained at $80 \mathrm{vol} \%$ of $\mathrm{Al}$ [29]. The high breakdown strength of PVDF has also been investigated by researchers introducing $3 \mathrm{D}$ $\mathrm{ZnO}$ superstructure [52]. The large remnant polarization in normal PVDF and PVDF-TrFE causes a low energy density. A study reported on the modified PVDF-TrFEto ferroelectric relaxor in which remnant polarization remained zero and acquired large energy density $>9 \mathrm{~J} / \mathrm{cm}^{3}$ and high dielectric strength $400 \mathrm{MV} / \mathrm{m}$. PVDF-TrFE(91/9 mol\%) shows $U>>$ $17 \mathrm{~J} / \mathrm{cm}^{3}$. PVDF and its copolymers promise a high energy density, but suffer from critical property defects such as the high dielectric and hysteresis losses, poor thermal stability, dielectric losses depending on the frequency and temperature, etc., which limits their use in industrial applications [17]. Composites of polystyrene show the almost frequency-independent dielectric behavior for $\mathrm{BaTiO}_{3}, \mathrm{TiO}_{2}$, and MWCNTPP fillers [43, 53, 54]. Polar polymers possess a good affinity for inorganic oxide fillers. Researchers use also cynoresin for the development of dielectric polymer composites due to its polar backbone. N. Madusanka et al. showed that $\mathrm{TiO}_{2} / \mathrm{CRS}$ possesses a high dielectric constant of 207 at $30 \mathrm{vol} \%$ of $\mathrm{TiO}_{2}$ [56]. Montmorillonite clay which is non-toxic and cheap increases the dielectric constant of CRS up to $10 \mathrm{vol} \%$ of $\operatorname{MMT}(k=49)$ [56]. Dielectric Properties of some polymer composites are listed in Table 2. 
Table 2. Dielectric properties of polymer composites

\begin{tabular}{|c|c|c|c|c|}
\hline Polymer & Filler & $k / U$ value & $\tan \delta / E_{b}$ & Ref. \\
\hline PVDF & 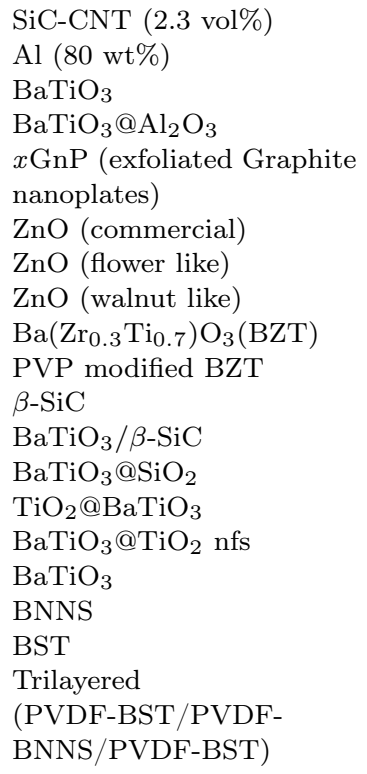 & $\begin{array}{c}k=8700 \\
k=230 \\
k=400-450 \\
k>10 \\
k>200 \\
k=19.4 \\
k=221.1 \\
k=104.9 \\
U=2.8 \mathrm{~J} / \mathrm{cm}^{3} \\
U=6.3 \mathrm{~J} / \mathrm{cm}^{3} \\
k=260 \\
k=325 \\
k=31.12-41.65 \\
U=12.2 \mathrm{~J} / \mathrm{cm}^{3} \\
k>41, U=20 \mathrm{~J} / \mathrm{cm}^{3} \\
k \sim 9.20-22.02 \\
U \sim 12.5 \mathrm{~J} / \mathrm{cm}^{3} \\
U \sim 10 \mathrm{~J} / \mathrm{cm}^{3} \\
U \sim 20 \mathrm{~J} / \mathrm{cm}^{3}\end{array}$ & $\begin{array}{c}\tan \delta=286 \\
\tan \delta=0.25 \\
- \\
\tan \delta=0.02 \\
\tan \delta=229 \\
E_{b}=45 \mathrm{kV} / \mathrm{mm} \\
E_{b}=42 \mathrm{kV} / \mathrm{mm} \\
E_{b}=40 \mathrm{kV} / \mathrm{mm} \\
E_{b}=400 \mathrm{kV} / \mathrm{mm} \\
E_{b}=380 \mathrm{kV} / \mathrm{mm} \\
\tan \delta=1.46 \\
\tan \delta=0.36 \\
\tan \delta=0.014-0.028 \\
E_{b}=340 \mathrm{kV} / \mathrm{mm} \\
E_{b}=650 \mathrm{kV} / \mathrm{mm} \\
E_{b} \sim 174-240 \mathrm{kV} / \mathrm{mm} \\
E_{b}=672 \mathrm{MV} / \mathrm{m} \\
- \\
E_{b}=588 \mathrm{MV} / \mathrm{m} \\
\tan \delta<0.05\end{array}$ & $\begin{array}{l}(22) \\
(29) \\
(41) \\
(59) \\
\\
(21) \\
(50) \\
(50) \\
(50) \\
(62) \\
(62) \\
(34) \\
(34) \\
(63) \\
(58) \\
(44) \\
(15) \\
(7) \\
(7) \\
(7) \\
(7)\end{array}$ \\
\hline $\mathrm{P}(\mathrm{VDF}-\operatorname{TrFE})$ & $\mathrm{CaCu}_{3} \mathrm{Ti}_{4} \mathrm{O}_{12}$ & $k=245-362$ & $\tan \delta=0.32-0.42$ & (1) \\
\hline $\mathrm{P}(\mathrm{VDF}-\mathrm{HFP})$ & (PFBPA-BT) & $U=3.2 \mathrm{~J} / \mathrm{cm}^{3}$ & $E_{b}>164 \mathrm{kV} / \mathrm{mm}$ & (12) \\
\hline P(VDF-CTFE) & $\begin{array}{l}\text { BNNSs/BT } \\
\text { BST }\end{array}$ & $\begin{array}{c}k \sim 8.0-15.3 \\
U=6.5 \mathrm{~J} / \mathrm{cm}^{3}\end{array}$ & $\begin{array}{l}E_{b} \sim 649 \mathrm{kV} / \mathrm{mm} \\
E_{b}>200 \mathrm{kV} / \mathrm{mm}\end{array}$ & $\begin{array}{l}(13) \\
(14)\end{array}$ \\
\hline PP & $\begin{array}{l}\mathrm{Al}_{2} \mathrm{O}_{3} @ \mathrm{Al} \\
\mathrm{PVDF} \text { (blend) } \\
\mathrm{SMA} / \mathrm{PVDF} \text { (blend) } \\
\mathrm{Al}_{2} \mathrm{O}_{3} \\
\mathrm{BaTiO}_{3}(\mathrm{BT}) \\
\mathrm{Al}_{2} \mathrm{O}_{3} / \mathrm{BT} \\
\mathrm{BaTiO}_{3} / \mathrm{TiO}_{2} \\
\mathrm{TiO}_{2} \\
\mathrm{BaTiO}_{3} \\
\mathrm{ZrO}_{2}\end{array}$ & 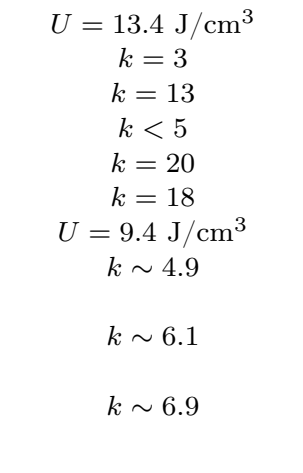 & $\begin{array}{c}E_{b}=75.8 \mathrm{kV} / \mathrm{mm} \\
\tan \delta<0.2 \\
\tan \delta<0.03 \\
\tan \delta<0.040 \\
\tan \delta<0.050 \\
\tan \delta<0.030 \\
E_{b} \sim 4 \mathrm{MV} / \mathrm{cm} \\
E_{b}>2.8 \mathrm{MV} / \mathrm{cm} \\
U \sim 0.2-2.8 \mathrm{~J} / \mathrm{cm}^{3} \\
E_{b}>5.9 \mathrm{MV} / \mathrm{cm}^{2} \\
U=9.4 \mathrm{~J} / \mathrm{cm}^{3} \\
E_{b}>2.0 \mathrm{MV} / \mathrm{cm}^{3} \\
U=1.02 \mathrm{~J} / \mathrm{cm}^{3}\end{array}$ & $\begin{array}{l}(58) \\
(47) \\
(47) \\
(35) \\
(35) \\
(35) \\
(38) \\
(16) \\
(16) \\
\\
(16)\end{array}$ \\
\hline PS & $\begin{array}{l}\mathrm{BaTiO}_{3} \\
\mathrm{TiO}_{2}(11.9 \mathrm{wt} \%) \\
\mathrm{TiO}_{2}(36.9 \mathrm{wt} \%) \\
\mathrm{TiO}_{2}(27 \mathrm{wt} \%) \\
\text { PMMA-BaTiO } \\
\text { MWCNT@PP(3\%) } \\
\text { MWCNT@PP(3\%) }\end{array}$ & $\begin{array}{c}k \sim 2.76-24.51 \\
k \sim 10 \\
k \sim 80 \\
k \sim 6.4 \\
U=2 \mathrm{~J} / \mathrm{cm}^{3} \\
k=4.3 \\
k=44\end{array}$ & $\begin{array}{c}\tan \delta \sim 0.013 \\
\tan \delta<0.05 \\
\tan \delta<0.15 \\
\tan \delta \sim 0.04 \\
E_{b}=220 \mathrm{kV} / \mathrm{mm} \\
\tan \delta \sim 0.005 \\
\tan \delta \sim 0.02\end{array}$ & $\begin{array}{l}(32) \\
(43) \\
(43) \\
(60) \\
(54) \\
(53) \\
(53)\end{array}$ \\
\hline LLDPE & $\begin{array}{l}\text { AlN (50 wt\%) } \\
\text { AlN (70 wt\%) }\end{array}$ & $\begin{array}{c}k=5 \\
k=6.9\end{array}$ & $\begin{array}{l}\tan \delta<0.085 \\
\tan \delta<0.085\end{array}$ & $\begin{array}{l}(29) \\
(29)\end{array}$ \\
\hline UHMWPE/LLDPE & $\begin{array}{l}\mathrm{Si}_{3} \mathrm{~N}_{4} \\
\mathrm{Al}_{2} \mathrm{O}_{3} / \mathrm{Si}_{3} \mathrm{~N}_{4}\end{array}$ & $\begin{array}{l}k=3.28 \\
k=3.19\end{array}$ & $\begin{aligned} \tan \delta & =4.68 \\
\tan \delta & =4.49\end{aligned}$ & $\begin{array}{l}(50) \\
(50)\end{array}$ \\
\hline LDPE & $\mathrm{Bi}_{2} \mathrm{~S}_{3}$ & $k=60$ & - & $(20)$ \\
\hline
\end{tabular}




\subsection{Application of dielectric polymer composites}

High dielectric constant materials are used to design high energy storage capacitors, pulsed power capacitors, gate dielectrics, epitaxial dielectrics, and dielectric elastomers $[3,45,64]$. Low dielectric constant polymer composites are used in the electrical insulating and packaging materials [3, 11]. Microwave dielectric materials have a wide range of applications such as the satellite communication and straddling terrestrial ones, including software radio, Global Positioning System (GPS), Direct Broadcast Satellite (DBS) TV, Internet of Things (IoT), environmental monitoring via satellites, dielectric resonators, substrates for microwave integrated circuits, etc. Tunable dielectric materials are used in antenna beam steering $[5,9]$.

\section{Conclusion}

- Achieving a high dielectric strength with improved dielectric constant is a major challenge.

- Inorganic ceramic fillers improve the dielectric constant of polymer composites; however, they reduce the dielectric strength and mechanical properties.

- The uniform dispersion of a filler and the low percolation threshold play a vital role in improving the dielectric properties.

- Core-shell structured and multi-layered composites ensure the improvement of the dielectric constant and a high dielectric strength at a low-level loading.

- To achieve a high energy density, materials should possess high $k$ and high dielectric strength values.

1. M. Arbatti, X. Shan, Z. Cheng. Ceramic-polymer composites with high dielectric constant. Adv Mater. 19 (10), 1369 (2007).

2. R. Popielarz, C.K. Chiang, R. Nozaki, J. Obrzut. Dielectric properties of polymer/ferroelectric ceramic composites from $100 \mathrm{~Hz}$ to $10 \mathrm{GHz}$. Macromolecules 34 (17), 5910 (2001).

3. S.M. Billah. Dielectric polymers, in Functional Polymers. Polymers and Polymeric Composites: A Reference Series. Edited by M. Jafar Mazumder, H. Sheardown, A. AlAhmed (Springer, Cham. 2018) [ISBN: 978-3-319-92067-2].

4. X. Huang, P. Jiang, T. Tanaka. A review of dielectric polymer composites with high thermal conductivity. IEEE Electrical Insulation Magazine 27 (4), 8 (2011).

5. M.T. Sebastian, H. Jantunen. Polymer-ceramic composites of 0-3 connectivity for circuits in electronics: A review. Int. J. Appl. Ceram. Technol. 7 (4), 415 (2010).
6. J.Y. Li, L. Zhang, S. Ducharme. Electric energy density of dielectric nanocomposites. Appl. Phys. Lett. 90 (13), 132901 (2007).

7. F. Liu, Q. Li, J. Cui, Z. Li, G. Yang, Y. Liu, L. Dong, C. Xiong, H. Wang, H.Q. Wang. High-energy-density dielectric polymer nanocomposites with trilayered architecture, Adv. Funct. Mater. 27 (20), 1606292 (2017).

8. B. Chu. A dielectric polymer with high electric energy density and fast discharge speed. Science $\mathbf{3 1 3}$ (5785), 334 (2006).

9. R. Ratheesh, M.T. Sebastian. Polymer ceramic composites for microwave applications. In: Microwave Materials and Applications. Edited by M.T. Sebastian, H. Jantunen, R. Ubic (Wiley Online Library, 2017), Vol. 2, Chap. 11, p. 481 [ISBN: 9781119208549].

10. M.T. Sebastian, L.K. Namitha. Rubber-ceramic composites. In: Microwave Materials and Applications (Wiley Online Library, 2017), Vol. 2, Chap. 12, p. 537 [ISBN: 9781119208549].

11. M. Xiao, B.X. Du. Review of high thermal conductivity polymer dielectrics for electrical insulation. High Volt. 1 (1), 34 (2016).

12. P. Kim, N.M. Doss, J.P. Tillotson, P.J. Hotchkiss, M.J. Pan, S.R. Marder, J. Li, J.P. Calame, J.W. Perry. High energy density nanocomposites based on surfacemodified $\mathrm{BaTiO}_{3}$ and a ferroelectric polymer. ACS Nano 3 (9), 2581 (2009).

13. Q. Li, K. Han, M.R. Gadinski, G. Zhang, Q. Wang. Energy storage: High energy and power density capacitors from solution-processed ternary ferroelectric polymer nanocomposites. Adv. Mater. 26 (36), 6244 (2014).

14. W. Xia, Z. Xu, F. Wen, Z. Zhang. Electrical energy density and dielectric properties of poly(vinylidene fluoridechlorotrifluoroethylene) $/ \mathrm{BaSrTiO}_{3}$ nanocomposites. $\mathrm{Ce}$ ram. Int. 38 (2), 1071 (2012).

15. P. Hu, Y. Shen, Y. Guan, X. Zhang, Y. Lin, Q. Zhang, C.W. Nan. Topological-structure modulated polymer nanocomposites exhibiting highly enhanced dielectric strength and energy density. Adv Funct Mater. 24 (21), 3172 (2014).

16. N. Guo, S.A. DiBenedetto, P. Tewari, M.T. Lanagan, M.A. Ratner, T.J. Marks. Nanoparticle, size, shape, and interfacial effects on leakage current density, permittivity, and breakdown strength of metal oxide-polyolefin nanocomposites: Experiment and theory. Chem. Mater. 22 (4), 1567 (2010).

17. S. Gupta, I. Offenbach, J.A. Ronzello, Y. Cao, S. Boggs, R.A. Weiss, M. Cakmak. Evaluation of poly(4-methyl-1pentene) as a dielectric capacitor film for high-temperature energy storage applications. J Polym. Sci. Part B Polym. Phys. 55 (20), 1497 (2017).

18. A. Rizvi, S.S. Bae, N.M.A. Mohamed, J.H. Lee, C.B. Park. Extensional Flow Resistance of 3D Fiber Networks in Plasticized Nanocomposites. Macromolecules 52 (17), 6467 (2019). 
19. K.S. Deepa, N.S. Kumari, P. Parameswaran, M.T. Sebastian, J. James. Effect of conductivity of filler on the percolation threshold of composites. Appl. Phys. Lett. 94 (14), 142902 (2009).

20. Y. Deng, N. Li, Y. Wang, Z. Zhang, Y. Dang, J. Liang. Enhanced dielectric properties of low density polyethylene with bismuth sulfide used as inorganic filler. Mater Lett. 64 (4), 528 (2010).

21. F. He, S. Lau, H.L. Chan, J. Fan. High dielectric permittivity and low percolation threshold in nanocomposites based on poly(vinylidene fluoride) and exfoliated graphite nanoplates. Adv. Mater. 21 (6), 710 (2009).

22. J.K. Yuan, W.L. Li, S.H. Yao, Y.Q. Lin, A. Sylvestre, J. Bai. High dielectric permittivity and low percolation threshold in polymer composites based on SiC-carbon nanotubes micro/nano hybrid. Appl. Phys. Lett. 98 (3), 032901 (2011).

23. T.S. Sasikala, M.T. Sebastian. Mechanical, thermal and microwave dielectric properties of $\mathrm{Mg}_{2} \mathrm{SiO}_{4}$ filled polyteterafluoroethylene composites. Ceram. Int. 42 (6), 7551 (2016).

24. H. Liu, L. Zhang, D. Yang, N. Ning, Y. Yu, L. Yao, B. Yan, M. Tian. A new kind of electro-active polymer composite composed of silicone elastomer and polyethylene glycol. J. Phys. D Appl. Phys. 45 (48), 485303 (2012).

25. M. Panda, V. Srinivas, A.K. Thakur. Role of polymer matrix in large enhancement of dielectric constant in polymermetal composites. Appl. Phys. Lett. 99 (4), 042905 (2011).

26. J. Varghese, N. Joseph, H. Jantunen, S.K. Behera, H.T. Kim, M.T. Sebastian. Microwave materials for defense and aerospace applications. In: Handbook of Advanced Ceramics and Composites. Edited by Y. Mahajan, J. Roy (Springer, 2019) [ISBN: 978-3-319-73255-8].

27. Y. Thakur, T. Zhang, C. Iacob, T. Yang, J. Bernholc, L.Q. Chen, J. Runt, Q.M. Zhang. Enhancement of the dielectric response in polymer nanocomposites with low dielectric constant fillers. Nanoscale 9 (31), 10992 (2017).

28. S. Gross, D. Camozzo, V. Di Noto, L. Armelao, E. Tondello. PMMA: A key macromolecular component for dielectric low-k hybrid inorganic-organic polymer films. Eur. Polym. J. 43 (3), 673 (2007).

29. W. Zhou. Thermal and dielectric properties of the aluminium particle reinforced linear low-density polyethylene composites. Polym. Eng. Sci. 51 (5), 917 (2011).

30. N. Madusanka, S.G. Shivareddy, P. Hiralal, M.D. Eddleston, Y. Choi, R.A. Oliver, G.A. Amaratunga. Nanocomposites of $\mathrm{TiO}_{2} /$ cyanoethylated cellulose with ultra high dielectric constants. Nanotechnology 27 (19), 195402 (2016).

31. M.P. Chun. Effect of particle size of BNT filler on dielectric and mechanical properties of LCP based composite. In: Applied Mechanics and Materials. Edited by Mohd Zulkifly Abdullah (Trans Tech Public., 2013), Vol. 483, p. 138.

32. K. Yang, X. Huang, L. Xie, C. Wu, P. Jiang, T. Tanaka. Core-shell structured polystyrene/ $\mathrm{BaTiO}_{3}$ hybrid nanodielectrics prepared by in situ RAFT polymerization: A route to high dielectric constant and low loss materials with weak frequency dependence, Macromol Rapid Commun. 33 (22), 1921 (2012).

33. K.S. Deepa, M.T. Sebastian, J. James. Effect of interparticle distance and interfacial area on the properties of insulator-conductor composites. Appl. Phys. Lett. 91 (20), 202904 (2007).

34. Y. Li, X. Huang, Z. Hu, P. Jiang, S. Li, T. Tanaka. Large dielectric constant and high thermal conductivity in poly(vinylidene fluoride)/barium titanate/silicon carbide three-phase nanocomposites. ACS Appl. Mater. Interfaces. 3 (11), 4396 (2011).

35. J. Yao, L. Hu, M. Zhou, F. You, X. Jiang, L. Gao, Q. Wang, Z. Sun, J. Wang. Synergistic enhancement of thermal conductivity and dielectric properties in $\mathrm{Al}_{2} \mathrm{O}_{3} / \mathrm{BaTiO}_{3} / \mathrm{PP}$ composites. Materials 11 (9), 1536 (2018).

36. X. Zhang, Y. Shen, B. Xu, Q. Zhang, L. Gu, J. Jiang, J. Ma, Y. Lin, C.W. Nan. Giant energy density and improved discharge efficiency of solution-processed polymer nanocomposites for dielectric energy storage. Adv. Mater. 28 (10), 2055 (2016).

37. M. Roy, J.K. Nelson, R.K. MacCrone, L.S. Schadler, C.W. Reed, R. Keefe. Polymer nanocomposite dielectrics the role of the interface. In: IEEE Transactions on Dielectrics and Electrical Insulation (IEEE, 2005), 12 (4), p. 629 .

38. N. Guo, S.A. DiBenedetto, D.K. Kwon, L. Wang, M.T. Russell, M.T. Lanagan, A. Facchetti, T.J. Marks. Supported metallocene catalysis for in situ synthesis of high energy density metal oxide nanocomposites, J. Am. Chem. Soc. 129 (4), 766 (2007).

39. S. Sugumaran, C.S. Bellan. Transparent nano composite PVA-TiO 2 and PMMA-TiO 2 thin films: Optical and dielectric properties. Optik 125 (18), 5128 (2014).

40. Z. Wang, J.K. Nelson, H. Hillborg, S. Zhao, L.S. Schadler. Graphene oxide filled nanocomposite with novel electrical and dielectric properties. Adv Mater. 24 (23), 3134 (2012).

41. D. Ramesh. One-step fabrication of biomimetic PVDF$\mathrm{BaTiO}_{3}$ nanofibrous composite using DoE. Mater. Res. Express. 5 (8), 085308 (2018).

42. A. Trajkovska. Inorganic dopants in polymer cholesteric liquid crystals. Maced. J. Chem. Chem. Eng. 34 (2), 381 (2015).

43. M. Crippa, A. Bianchi, D. Cristofori, M. D'Arienzo, F. Merletti, F. Morazzoni, R. Scotti, R. Simonutti. High dielectric constant rutile-polystyrene composite with enhanced percolative threshold. J. Mater. Chem. C 1 (3), 484 (2013).

44. X. Zhang, Y. Shen, Q. Zhang, L. Gu, Y. Hu, J. Du, Y. Lin, C.W. Nan. Ultrahigh energy density of polymer nanocomposites containing $\mathrm{BaTiO}_{3}-\mathrm{TiO}_{2}$ nanofibers by atomicscale interface engineering. Adv. Mater. 27 (5), 819 (2015).

45. Y. Shen, Y. Lin, Q.M. Zhang. Polymer nanocomposites with high energy storage densities. MRS. Bull. 40 (9), 753 (2015).

46. B.K. Sharma, A.K. Gupta, N. Khare, S.K. Dhawan, H.C. Gupta. Synthesis and characterization of polyaniline-

ISSN 2071-0194. Ukr. J. Phys. 2021. Vol. 66, No. 2 
$\mathrm{ZnO}$ composite and its dielectric behavior. Synth. Met. 159 (5-6), 391 (2009).

47. Z. Chen, J. Pei, R. Li. Study of the preparation and dielectric property of PP/SMA/PVDF blend material, Appl. Sci. 7 (4), 389 (2017).

48. C. Yang, H. Li, D. Xiong, Z. Cao. Hollow polyaniline $/ \mathrm{Fe}_{3} \mathrm{O}_{4}$ microsphere composites: Preparation, characterization, and applications in microwave absorption. React. Funct. Polym. 69 (2), 137 (2009).

49. J. Gu, X. Meng, Y. Tang, Y. Li, Q. Zhuang, J. Kong. Hexagonal boron nitride/polymethyl-vinyl siloxane rubber dielectric thermally conductive composites with ideal thermal stabilities. Compos. Part A Appl. Sci. Manuf. 92, 27 (2017).

50. W. Zhou, C. Wang, T. Ai, K. Wu, F. Zhao, H. Gu. A novel fiber-reinforced polyethylene composite with added silicon nitride particles for enhanced thermal conductivity. Compos. Part A Appl. Sci. Manuf. 40 (6-7), 830 (2009).

51. W. Zhou, J. Zuo, W. Ren. Thermal conductivity and dielectric properties of $\mathrm{Al} / \mathrm{PVDF}$ composites. Compos. Part A Appl. Sci. Manuf. 43 (4), 658 (2012).

52. W. Wu, X. Huang, S. Li, P. Jiang, T. Toshikatsu. Novel three-dimensional zinc oxide superstructures for high dielectric constant polymer composites capable of withstanding high electric field. J. Phys. Chem. C. 116 (47), 24887 (2012).

53. C. Yang, Y. Lin, C.W. Nan. Modified carbon nanotube composites with high dielectric constant, low dielectric loss and large energy density. Carbon 47 (4), 1096 (2009).

54. S.A. Paniagua, Y. Kim, K. Henry, R. Kumar, J.W. Perry, S.R. Marder. Surface-initiated polymerization from barium titanate nanoparticles for hybrid dielectric capacitors. ACS Appl. Mater. Interfaces 6 (5), 3477 (2014).

55. K.S. Shah, R.C. Jain, V. Shrinet, A.K. Singh, D.P. Bharambe. High density polyethylene (HDPE) clay nanocomposite for dielectric applications. In: IEEE Transaction on Dielectrics and Electrical Insulation (IEEE, 2009), 16 (3), p. 853 .

56. N. Madusanka, S.G. Shivareddy, M.D. Eddleston, P. Hiralal, R.A. Oliver, G.A.J. Amaratunga. Dielectric behavior of montmorillonite/cyanoethylated cellulose nanocomposites. Carbohydr. Polym. 172, 315 (2017).

57. Q. Li, L. Chen, M.R. Gadinski, S. Zhang, G. Zhang, H.U. Li, E. Iagodkine, A. Haque, L.Q. Chen, T.N. Jackson, Q. Wang. Flexible high-temperature dielectric materials from polymer nanocomposites. Nature $\mathbf{5 2 3}$ (7562), 576 (2015).

58. X. Huang, P. Jiang. Core-shell structured high-k polymer nanocomposites for energy storage and dielectric applications. Adv. Mater. 27 (3), 546 (2015).

59. D. He, Y. Wang, X. Chen, Y. Deng. Core-shell structured $\mathrm{BaTiO}_{3}-\mathrm{Al}_{2} \mathrm{O}_{3}$ nanoparticles in polymer composites for dielectric loss suppression and breakdown strength enhancement, Compos. Part A Appl. Sci. Manuf. 93, 137 (2017).

ISSN 2071-0194. Ukr. J. Phys. 2021. Vol. 66, No. 2
60. M.N. Tchoul, S.P. Fillery, H. Koerner, L.F. Drummy, F.T. Oyerokun, P.A. Mirau, M.F. Durstock, R.A. Vaia. Assemblies of titanium dioxide-polystyrene hybrid nanoparticles for dielectric applications. Chem. Mater. 22 (5), 1749 (2010).

61. T.I. Yang, C.Y. Chuang, S.C. Yang, L.C. Kempel, P. Kofinas. Core/shell iron/oxide nanoparticles for improving the magneto-dielectric properties of polymer composites. Adv. Eng. Mater. 18 (1), 121 (2016).

62. S. Liu, S. Xue, S. Xiu, B. Shen, J. Zhai. Surface-modified $\mathrm{Ba}\left(\mathrm{Zr}_{0.3} \mathrm{Ti}_{0.7}\right) \mathrm{O}_{3}$ nanofibers by polyvinylpyrrolidone filler for poly(vinylidene fluoride) composites with enhanced dielectric constant and energy storage density. Sci. Rep. 6 , 26198 (2016).

63. Z. Zhang, Y. Gu, J. Bi, S. Wang, M. Li, Z. Zhang. Tunable BT- $\mathrm{SiO}_{2}$ core@shell filler reinforced polymer composite with high breakdown strength and release energy density. Compos. Part A Appl. Sci. Manuf. 85, 172 (2016).

64. M. Laad. Extraction and characterization of silica from agro-waste for energy applications. In: International Conference on Energy, Communication, Data Analytics and Soft Computing (ICECDS) (IEEE, 2017), p. 1946.

Received 21.03.20

\section{Б. Гхуле, М. Лаад}

\section{ПОЛІМЕРНІ КОМПОЗИТИ З ПОЛІПШЕНИМИ ДІЕЛЕКТРИЧНИМИ ВЛАСТИВОСТЯМИ: ОГЛЯД}

Матеріали з високим значенням діелектричної константи $(k)$ застосовуються в конденсаторах, як ізолюючий шар у затворах, в діелектричних еластомерах, акумуляторах енергії, тоді як матеріали з малим $k$ потрібні для електронного монтажу і в багатьох інших випадках. Традиційно матеріали з високим значенням $k$ характеризуються значними діелектричними втратами, залежністю властивостей від частоти і великим навантаженням на наповнювач. Матеріали 3 малим $k$ мають низьку теплопровідність. Все це створюе нові завдання у розробці діелектричних матеріалів для обох видів застосування. Використання наповнювачів з високим значенням діелектричної константи дає збільшення сумарної $k$. Ми вивчаємо вплив різних параметрів і факторів на діелектричні властивості матеріалів, а саме: тип полімеру, матеріал наповнювача, розмір, форма, рівень навантаження, модифікація поверхні матеріалу наповнювача і спосіб приготування полімерного композита. Роботу спрямовано на поліпшення діелектричних характеристик полімерних нанокомпозитів, які застосовуються у пристроях для накопичення енергії. Результати показують, що підхід зі структурованими ядром і оболонкою для матеріалів з великим $k$, введеними в полімерну матрицю, дозволяє покращити діелектричні властивості полімерних композитів.

Ключові слова: полімерні композити, діелектрична константа, електрична міцність діелектрика, керамічний наповнювач, накопичення енергії. 